\title{
Pazopanib versus sunitinib in Chinese patients with locally advanced or metastatic renal cell carcinoma: pooled subgroup analysis from the randomized, COMPARZ studies
}

Xinan Sheng ${ }^{1}$, Jie Jin ${ }^{2}$, Zhisong He ${ }^{2}$, Yiran Huang ${ }^{3}$, Aiping Zhou ${ }^{4}$, Jinwan Wang ${ }^{4}$, Xiubao Ren ${ }^{5}$, Dingwei Ye ${ }^{6}$, Xu Zhang ${ }^{7}$, Shukui Qin ${ }^{8}$, Fangjian Zhou', Binhui Wang ${ }^{10}$ and Jun Guo ${ }^{1 *}$

\begin{abstract}
Background: We performed a pooled analysis of the COMPARZ study assessing efficacy and safety of pazopanib versus sunitinib in treatment-naïve Chinese patients with locally advanced and/or metastatic renal cell carcinoma (a/mRCC).

Methods: In the COMPARZ study, patients were randomized (1:1) to receive pazopanib 800 mg once daily (QD) continuously or sunitinib $50 \mathrm{mg}$ QD in 6-week cycles (4 weeks on, 2 weeks off). The primary endpoint was progression-free survival (PFS); secondary endpoints included overall response rate (ORR), overall survival (OS), and safety. PFS and ORR were assessed by independent review committee (IRC) and local investigators.

Results: Of the 209 Chinese patients (pazopanib, [n=109] and sunitinib, $[n=100]), 155$ (74\%) were males and median age was 57 years (range, 18-79). Median PFS was 13.9 months for pazopanib versus 14.3 months for sunitinib per investigator assessment and 8.3 months in both arms per IRC assessment; PFS hazard ratio was 1.17 (investigator) and 0.99 (IRC). Median OS was not reached in pazopanib arm and was 29.5 months in sunitinib arm. ORR was significantly higher in pazopanib arm versus sunitinib arm (investigator: $41 \%$ versus $23 \%[P=0.0052]$; IRC: $35 \%$ versus 20\% $[P=0.0203])$. Pazopanib was generally well tolerated in Chinese patients with $\mathrm{a} / \mathrm{mRCC}$. Most frequent AEs in the pazopanib arm were diarrhea and hair color changes whereas the most frequent AEs in the sunitinib arm were decreased platelets, decreased neutrophil count, and thrombocytopenia.
\end{abstract}

Conclusion: The results of the pooled analysis were consistent with the overall population in the COMPARZ study, and confirmed similar PFS and OS of pazopanib and sunitinib in the Chinese patients.

Trial registration: clinical trials.gov, NCT00720941 (August 14, 2008) and NCT01147822 (May 19, 2010).

Keywords: Renal cell carcinoma, Pazopanib, Sunitinib, Chinese

\footnotetext{
* Correspondence: guoj307@126.com

${ }^{1}$ Key Laboratory of Carcinogenesis and Translational Research (Ministry of Education/Beijing), Department of Renal Cancer and Melanoma, Peking University Cancer Hospital \& Institute, Beijing, China

Full list of author information is available at the end of the article
}

(c) The Author(s). 2020 Open Access This article is licensed under a Creative Commons Attribution 4.0 International License, which permits use, sharing, adaptation, distribution and reproduction in any medium or format, as long as you give appropriate credit to the original author(s) and the source, provide a link to the Creative Commons licence, and indicate if changes were made. The images or other third party material in this article are included in the article's Creative Commons licence, unless indicated otherwise in a credit line to the material. If material is not included in the article's Creative Commons licence and your intended use is not permitted by statutory regulation or exceeds the permitted use, you will need to obtain permission directly from the copyright holder. To view a copy of this licence, visit http://creativecommons.org/licenses/by/4.0/. The Creative Commons Public Domain Dedication waiver (http://creativecommons.org/publicdomain/zero/1.0/) applies to the data made available in this article, unless otherwise stated in a credit line to the data. 


\section{Background}

Renal cell carcinoma (RCC) is the most common form of kidney cancer (approximately 90\%) with clear cell RCC constituting approximately 75 to $80 \%$ of RCC [1]. As per the National Cancer Registry of China, there were 45,096 new RCC cases in 2011, accounting for $1.34 \%$ of all malignancies. RCC accounted for $0.5 \%$ of all cancer deaths and ranked 16th among all cancers [2]. According to the Chinese Cancer Registry's annual report of 2015, the incidence and mortality of RCC were higher in males versus females, (male/female ratio of 2: 1) and also higher in urban areas than in rural areas [2].

In China, the approved agents for the treatment of metastatic RCC include the tyrosine kinase inhibitors (TKIs; pazopanib, sunitinib, sorafenib, axitinib) and the mammalian target of rapamycin (mTOR) inhibitor, everolimus [2]. In addition, there are ongoing studies for immune checkpoint inhibitors like nivolumab [3]. Pazopanib and sunitinib are first-line agents acting on the vascular endothelial growth factor receptors (VEGFRs) 1, 2, 3 as well as platelet-derived growth factor receptors and other tyrosine kinases [4]. Single agent TKI treatment remains important in China where pembrolizumab+axitinib and nivolumab+ipilimumab are not available. Differences have been reported in the efficacy and safety seen with TKIs in Chinese patients compared to Western patients [5-7].

The COMPARZ study evaluated the relative efficacy and safety profiles of first-line pazopanib and sunitinib in patients with advanced or metastatic RCC and demonstrated that that the efficacy of these drugs is comparable, but that there were significant differences in safety profiles and patient quality-of-life [8]. The objective of the pooled analysis from the COMPARZ study was to compare the efficacy and safety profiles of pazopanib and sunitinib in Chinese patients with locally advanced or metastatic RCC.

\section{Methods}

Detailed eligibility criteria, study design, efficacy endpoints, and statistical methods of the COMPARZ trial have been reported previously [8].

\section{Patients}

The key inclusion criteria were diagnosis of RCC with clear-cell component histology, locally advanced or metastatic disease, patients who received no prior systemic therapy (interleukin-2, interferon alpha, chemotherapy, bevacizumab, mTOR inhibitor, sunitinib, sorafenib, or other VEGF TKI) for advanced or metastatic RCC, measurable disease per Response Evaluation Criteria In Solid Tumors (RECIST) v1.0, Karnofsky performance scale value of $\geq 70$, and adequate organ system functions.

The key exclusion criteria included history of another malignancy, history or clinical evidence of central nervous system metastases, poorly controlled hypertension, history of cardiovascular conditions, any serious and/or unstable preexisting medical, psychiatric, or other conditions that could interfere with patient's safety, obtaining informed consent, or compliance to the study, prior use of an investigational or licensed drug that targets VEGF or VEGFRs (eg, bevacizumab, sunitinib, sorafenib, etc), or use of mTOR inhibitors (eg, temsirolimus, everolimus, etc).

\begin{tabular}{|l|l|l|l|}
\hline Sign & \multicolumn{3}{|c|}{ Stratification/ } \\
Informed \\
Randomization (1:1)/
\end{tabular}




\section{Study design}

The COMPARZ study was a randomized, open-label, parallel-group, phase 3 trial, which evaluated the efficacy and safety of pazopanib versus sunitinib in patients with advanced or metastatic RCC. The study design has been reported previously [8]. NCT01147822 was designed as a substudy of NCT00720941 to compare the efficacy and safety of pazopanib versus sunitinib in Asian population [8]. In total, 209 Chinese patients were enrolled in the COMPARZ study. Eighty patients were enrolled in NCT00720941 from 10 Oct 2009 to 26 Apr 2010, and 129 patients were enrolled in NCT01147822 from 26 May 2010 to 30 Sep 2011. Written informed consent was obtained from each patient before performing any study-specific procedures.

Randomization was stratified for Karnofsky Performance Scale of $70-80$ or $90-100$, baseline levels of lactate dehydrogenase ( $>1.5$ versus $\leq 1.5$ times upper limit of normal), and previous nephrectomy (yes versus no). Eligible patients were centrally randomized 1 : 1 to receive either pazopanib $800 \mathrm{mg}$ once daily (QD) continuously or sunitinib $50 \mathrm{mg}$ QD in 6-week cycles (4 weeks of treatment followed by 2 weeks without treatment). Patients received treatment until disease progression per investigator (RECIST 1.0), death, unacceptable toxicity, or consent withdrawal for any reason.

\section{Endpoints and assessments}

The primary objective was to compare the progressionfree survival (PFS) of patients treated with pazopanib versus sunitinib. The secondary objectives were to compare the overall survival (OS), overall response rate (ORR), time to response, duration of response (DOR), and safety in RCC patients treated with pazopanib versus sunitinib.

Efficacy assessments were scheduled at screening/baseline with follow-up every 6 weeks till week 24 , and then every 12 weeks thereafter until progressive disease (PD), death, unacceptable toxicity, or withdrawal of consent (Fig. 1). Computed tomography or magnetic resonance imaging data were evaluated by investigators and reevaluated by an independent review committee (IRC). Safety assessments were evaluated every 6 weeks until week 24, and every 12 weeks thereafter until progression of disease [8].

\section{Statistical analysis}

The treatment HR for PFS analysis was estimated by a Cox model. For each treatment arm, the Kaplan-Meier survival curves were presented. A sensitivity analysis of IRC-assessed PFS was performed to explore the robustness of the results of the primary analysis. This sensitivity analysis was similar to the primary analysis except that the analysis did not use the stratification factors to adjust/stratify the analysis. Overall survival was summarized using Kaplan-Meier survival curves and compared between treatment arms using a log-rank test.

Table 1 Summary of baseline characteristics (Chinese ITT population)

\begin{tabular}{|c|c|c|c|c|}
\hline & Pazopanib & Sunitinib & Total & $\begin{array}{l}P \\
\text { value }\end{array}$ \\
\hline Number of patients & 109 & 100 & 209 & \\
\hline Age, (years) & & & & 0.8991 \\
\hline Mean (SD) & $55.5(11.57)$ & $55.7(11.16)$ & $55.6(11.35)$ & \\
\hline Median (min, max) & $58(18,76)$ & $57(23,79)$ & $57(18,79)$ & \\
\hline
\end{tabular}

Sex, n (\%)

0.5611

Female

$30(28)$

$24(24)$

$54(26)$

Male

$79(72)$

$76(76)$

$155(74)$

Weight (kg), n (\%)

$66.44 \quad 67.02 \quad 66.72$

(12.665) (12.414) (12.519)

Median (min, max) $67(36,110) \quad 66(40,95) \quad 67(36,110)$

Primary tumor type, $\mathbf{n}(\%)$

NA

Renal cell

$109(100) \quad 100(100) \quad 209(100)$

Histology, n (\%)

$\begin{array}{llll}\text { Clear cell } & 107(98) & 96(96) & 203(97) \\ \begin{array}{l}\text { Predominantly clear } \\ \text { cell }\end{array} & 2(2) & 4(4) & 6(3)\end{array}$

Stage at screening, $\mathrm{n}(\%)$

॥

III

$1(<1)$

0

$1(<1)$

$1(<1)$

6 (3)

IV $\quad 104(95) \quad 96(96) \quad 200(96)$

Missing

$1(<1)$

0

$1(<1)$

Metastatic disease at screening, $n$ (\%)

No

Missing

$2(2)$

$3(3)$

$5(2)$

$1(<1)$

0.1588

MSKCC risk category, n (\%)

$\begin{array}{llll}\text { Favorable risk } & 26(24) & 34(34) & 60(29) \\ \text { Intermediate risk } & 75(69) & 64(64) & 139(67) \\ \text { Poor risk } & 6(6) & 2(2) & 8(4) \\ \text { Unknown } & 2(2) & 0 & 2(<1)\end{array}$

Heng risk category, $\mathrm{n}(\%)$

0.2168

$\begin{array}{llll}\text { Favorable risk } & 24(22) & 33(33) & 57(27) \\ \text { Intermediate risk } & 70(64) & 55(55) & 125(60) \\ \text { Poor risk } & 14(13) & 12(12) & 26(12) \\ \text { Unknown } & 1(<1) & 0 & 1(<1)\end{array}$

ITT Intent to treat, MSKCC Memorial Sloan-Kettering Cancer Center, $S D$ Standard deviation 


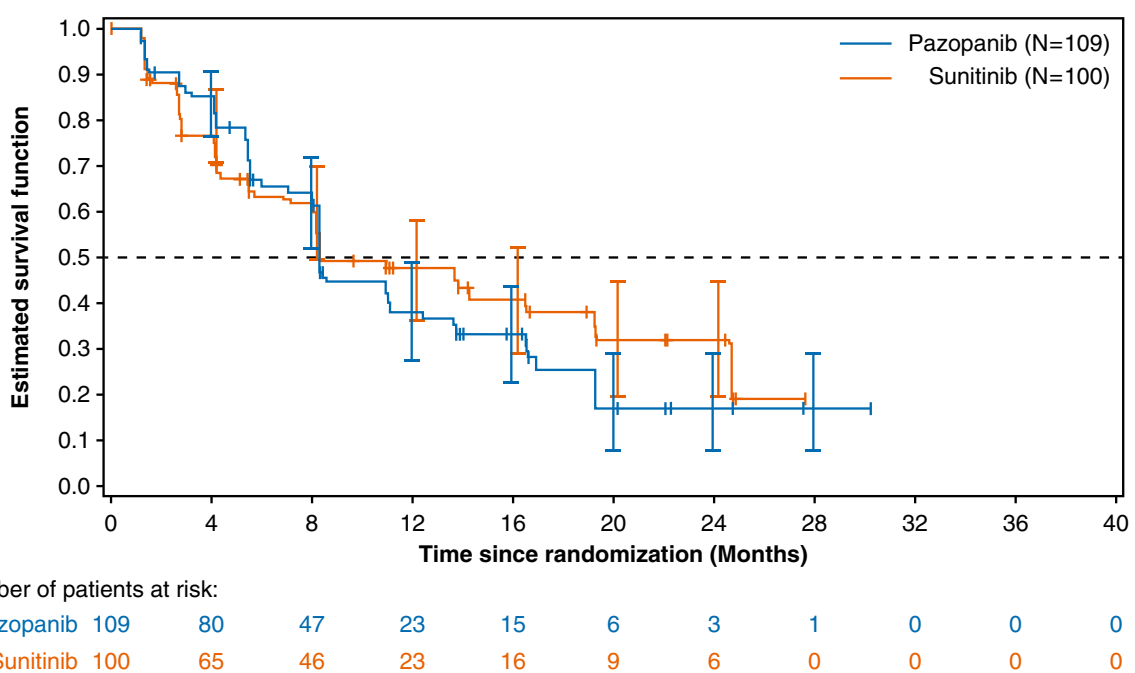

Fig. 2 Kaplan-Meier progression-free survival curves

\section{Results \\ Patients}

A total of 230 patients were screened and 209 patients (109 randomized to pazopanib and 100 to sunitinib) were enrolled in China. The median age was 57 years (range, 1879 years), with more men than women enrolled as expected for the disease population. The disease characteristics at initial diagnosis and at screening were balanced between the two treatment arms (Table 1), with the exception of median time since initial diagnosis, which was observed to be longer in the sunitinib arm (198 days; interquartile range [IQR]: 34, 984) than in the pazopanib arm (89 days; IQR: 30, 760). The most common disease locations at baseline were the lung, kidney, lymph nodes, and bone.

\section{Efficacy results}

In the Chinese subgroup, the efficacy results of pazopanib were similar to sunitinib in terms of PFS, OS, and ORR. The IRC-assessed PFS HR was 0.9927 (95\% CI, 0.6760-1.4580). The HR for the Chinese population was consistent with the IRC-assessed PFS for the overall population in the COMPARZ study (HR, 1.047; 95\% CI, $0.8982-1.2195)$. The median PFS in the pazopanib arm (8.3 months; 95\% CI, 8.2-11.1) was similar as that in the sunitinib arm (8.3 months; 95\% CI, 8.1-19.3) (Fig. 2), which shows that the efficacy of pazopanib was similar to that of sunitinib in the Chinese population (Table 2).

The investigator-assessed PFS HR was 1.169 (95\% CI, 0.792-1.727). The median PFS was 13.9 months for pazopanib versus 14.3 months for sunitinib. The results of the sensitivity analysis for PFS (HR 1.077, 95\% CI: 0.740-1.569) were consistent with the results of the primary analysis suggesting that PFS was similar for pazopanib and sunitinib.

The OS was similar between the two treatment arms (Fig. 3). The HR for median OS was 0.938 (95\% CI, 0.583-
1.510; $P=0.792$ ). The median OS was 29.5 months (IQR: $12.1,29.8$ ) in the sunitinib arm but was not yet reached in the pazopanib arm (IQR: 12.6, not reached).

The response rate (complete response $[\mathrm{CR}]+$ partial response $[\mathrm{PR}]$ ) in the pazopanib arm was higher compared to the sunitinib arm based on IRC assessment (35\% versus $20 \%$, respectively) and the difference (15\%) was statistically significant $(P=0.02)$. Consistent with the IRC-assessed response, the investigator-assessed response rate was also higher in the pazopanib arm than the sunitinib arm, and the difference $(18 \%)$ was statistically significant $(P=0.005)$. The median time to IRC-assessed response was 11.9 weeks (IQR: $6.3,18.0$ ) in the pazopanib arm and 12.1 weeks (IQR: $11.3,18.0)$ in the sunitinib arm. DOR data is inconclusive due to small number of responders in each arm (38/109 in pazopanib and 20/100 in sunitinib) and it is not statistically valid to compare them.

\section{Safety results}

The most common adverse events (AEs; > 35\% in either of the treatment arms) were hypertension, diarrhea,

Table 2 Efficacy assessments

\begin{tabular}{|c|c|c|c|c|}
\hline \multirow[t]{2}{*}{ Parameter } & \multicolumn{2}{|l|}{$\begin{array}{l}\text { Investigator } \\
\text { assessment }\end{array}$} & \multicolumn{2}{|c|}{ IRC assessment } \\
\hline & Pazopanib & Sunitinib & Pazopanib & Sunitinib \\
\hline Number of patients & 109 & 100 & 109 & 100 \\
\hline $\begin{array}{l}\text { Median PFS (1st quartile, } \\
\text { 3rd quartile) months }\end{array}$ & $\begin{array}{l}13.9(8.0 \\
20.2)\end{array}$ & $\begin{array}{l}14.3(5.6 \\
27.7)\end{array}$ & $\begin{array}{l}8.3(5.5 \\
19.3)\end{array}$ & $\begin{array}{l}8.3(4.1 \\
24.7)\end{array}$ \\
\hline HR $(95 \% \mathrm{Cl})$ & \multicolumn{2}{|c|}{$\begin{array}{l}1.17(0.792-1.727) \\
P=0.4381\end{array}$} & \multicolumn{2}{|c|}{$\begin{array}{l}0.99(0.6760-1.4580) \\
P=0.9629\end{array}$} \\
\hline \multirow[t]{2}{*}{ ORR, \% } & 41 & 23 & 35 & 20 \\
\hline & \multicolumn{2}{|l|}{$P=0.0052$} & \multicolumn{2}{|l|}{$P=0.0203$} \\
\hline
\end{tabular}

Cl Confidence interval, HR Hazard ratio, IRC Independent review committee, ORR Overall response rate, PFS Progression-free survival 


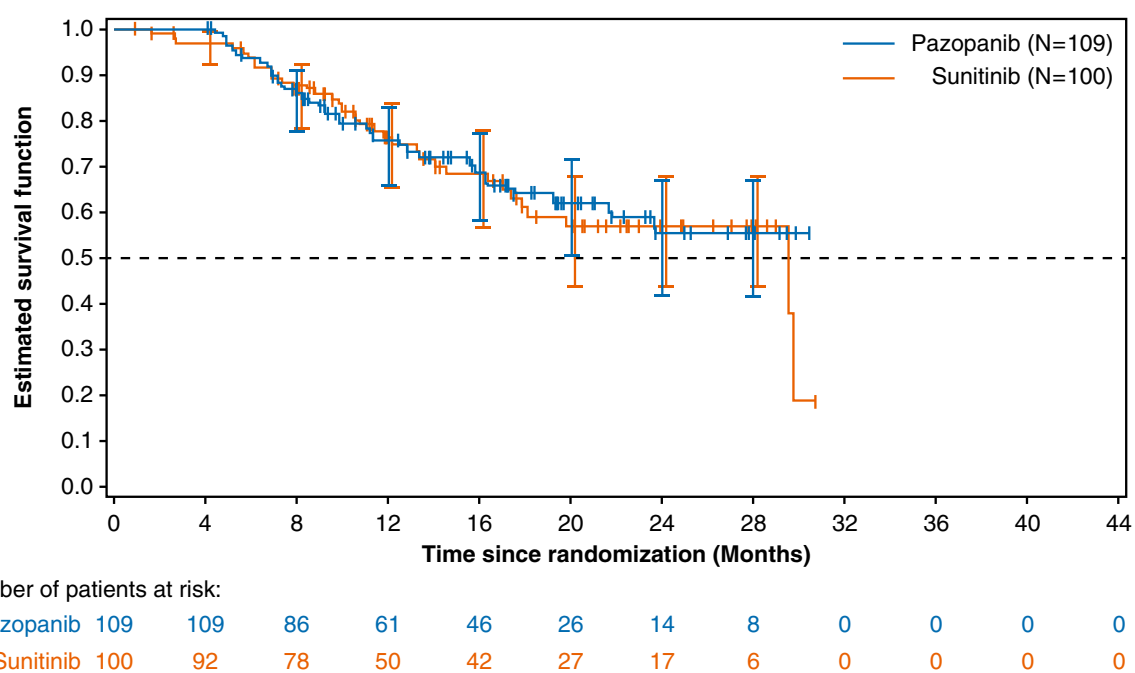

Fig. 3 Kaplan-Meier overall survival curves

hand-foot syndrome (HFS), hair color changes, increased alanine aminotransferase (ALT), increased aspartate aminotransferase (AST), fatigue, decreased appetite, proteinuria, leukopenia, neutropenia, decreased neutrophil count, decreased platelet count, and thrombocytopenia; these AEs were consistent with those commonly observed for the class of VEGF TKI.

Of the AEs occurring in $\geq 10 \%$ of patients in either of the treatment arms (Table 3), the following AEs occurred more frequently (95\% CI for relative risk excluding one, unadjusted for multiplicity) in the sunitinib arm compared to the pazopanib arm: increased blood creatinine, decreased white blood cell count, decreased neutrophil count, decreased platelets and thrombocytopenia, eyelid edema, decreased hemoglobin, increased blood lactate dehydrogenase, increased blood thyroid stimulating hormone, peripheral edema, stomatitis, anemia, nasopharyngitis, facial edema, yellow skin, and xanthochromia. AEs occurring more frequently ( $95 \%$ CI for relative risk excluding one, unadjusted for multiplicity) in the pazopanib arm compared to the sunitinib arm were diarrhea, hair color changes, and skin hypopigmentation (Table 4).

\section{Discussion}

The study results suggest that both pazopanib and sunitinib can effectively improve the OS and PFS in Chinese patients with locally advanced or metastatic RCC in first-line treatment. The results of the Chinese subgroup analysis were mostly consistent with the overall population in the COMPARZ study.

Although the ORR in pazopanib arm was significantly higher than sunitinib arm, it did not translate into a PFS advantage over sunitinib. The IRC and investigator assessed median PFS values for the Chinese subgroup were similar in both arms. The difference between the IRC and the investigator-assessed PFS in terms of HR and median PFS could be due to the relatively small sample size in the Chinese subgroup and potential difference in judgment of tumor progression between the investigators and IRC. This is also not indicative that the investigators necessarily assess sunitinib as better given the small sample size and does not affect the consistency in terms of PFS as assessed by IRC between the Chinese subgroup and overall population in the COMPARZ study. The OS was similar between the pazopanib and sunitinib arms of Chinese subgroup. The efficacy endpoints observed in sunitinib arm of Chinese subgroup were comparable to those reported in previous studies [9-11]. Therefore, the data generated from this Chinese subgroup analysis are relevant to clinical practice.

Overall, the difference of safety between pazopanib and sunitinib arms observed in the Chinese subgroup was similar to overall population in the COMPARZ study. In the Chinese subgroup, hematological toxicities (anemia, leukopenia, lymphopenia, neutropenia, and thrombocytopenia) occurred less frequently in the pazopanib versus sunitinib arm. Hepatobiliary events (increased bilirubin, grade 3 or 4 increased ALT and AST) occurred less frequently in the sunitinib versus pazopanib arm. However, most cases of increased ALT/AST were grade $1 / 2$, and no fatal liver events occurred in the Chinese subgroup. Compared to the results of the overall population in the COMPARZ study, hematological toxicities, hepatobiliary events and fatigue occurred less frequently in Chinese subgroup, while hypertension, HFS, hair color changes occurred more frequently in the Chinese subgroup [8]. The AE profile seen in Chinese subgroup was consistent with the results reported previously for other VEGF TKIs (sunitinib and sorafenib) in clinical practice [11-13]. In the era of immunotherapy, pazopanib and sunitinib are still preferential options in 
Table 3 Summary of on-therapy adverse events occurring in $\geq 10 \%$ of patients in either of the treatment arms (Chinese safety population)

\begin{tabular}{|c|c|c|}
\hline Adverse event & $\begin{array}{l}\text { Pazopanib } \\
\boldsymbol{N}=109 \\
\mathrm{n}(\%)\end{array}$ & $\begin{array}{l}\text { Sunitinib } \\
\boldsymbol{N}=100 \\
\mathrm{n}(\%)\end{array}$ \\
\hline Patients with any event & $108(>99)$ & $99(99)$ \\
\hline Hypertension & $65(60)$ & $50(50)$ \\
\hline Diarrhea & $57(52)$ & $37(37)$ \\
\hline Palmar-plantar erythrodysesthesia syndrome (HFS) & $52(48)$ & $57(57)$ \\
\hline Hair color changes & $47(43)$ & $13(13)$ \\
\hline Alanine aminotransferase increased & $45(41)$ & $32(32)$ \\
\hline Fatigue & $43(39)$ & $41(41)$ \\
\hline Aspartate aminotransferase increased & $41(38)$ & $32(32)$ \\
\hline Decreased appetite & $41(38)$ & $32(32)$ \\
\hline Proteinuria & $39(36)$ & $39(39)$ \\
\hline Leukopenia & $33(30)$ & $43(43)$ \\
\hline Blood bilirubin increased & $27(25)$ & $21(21)$ \\
\hline Neutropenia & $26(24)$ & $36(36)$ \\
\hline Neutrophil count decreased & $25(23)$ & $40(40)$ \\
\hline Platelet count decreased & $23(21)$ & $39(39)$ \\
\hline Blood creatinine increased & $21(19)$ & $32(32)$ \\
\hline Thrombocytopenia & $20(18)$ & $39(39)$ \\
\hline Nausea & $19(17)$ & $15(15)$ \\
\hline Vomiting & $19(17)$ & $9(9)$ \\
\hline Hypothyroidism & $18(17)$ & $23(23)$ \\
\hline Mouth ulceration & $17(16)$ & $25(25)$ \\
\hline White blood cell count decreased & $17(16)$ & $33(33)$ \\
\hline Eyelid edema & $16(15)$ & $28(28)$ \\
\hline Abdominal pain upper & $15(14)$ & $7(7)$ \\
\hline Bilirubin conjugated increased & $15(14)$ & $6(6)$ \\
\hline Blood bilirubin unconjugated increased & $15(14)$ & $8(8)$ \\
\hline Hemoglobin decreased & $13(12)$ & $31(31)$ \\
\hline Skin hypopigmentation & $13(12)$ & $3(3)$ \\
\hline Blood triglycerides increased & $12(11)$ & $14(14)$ \\
\hline Blood lactate dehydrogenase increased & $9(8)$ & $18(18)$ \\
\hline Epistaxis & $9(8)$ & $11(11)$ \\
\hline Hypogeusia & $9(8)$ & $12(12)$ \\
\hline Pain in extremity & $9(8)$ & $12(12)$ \\
\hline Rash & $9(8)$ & $14(14)$ \\
\hline Blood thyroid stimulating hormone increased & $8(7)$ & $19(19)$ \\
\hline Anemia & $7(6)$ & $25(25)$ \\
\hline Dysgeusia & $6(6)$ & $12(12)$ \\
\hline Peripheral edema & $6(6)$ & $14(14)$ \\
\hline Blood cholesterol increased & $5(5)$ & $10(10)$ \\
\hline Stomatitis & $4(4)$ & $12(12)$ \\
\hline Facial edema & $3(3)$ & $17(17)$ \\
\hline Yellow skin & $3(3)$ & $22(22)$ \\
\hline Nasopharyngitis & $2(2)$ & $10(10)$ \\
\hline Xanthochromia & $1(<1)$ & $10(10)$ \\
\hline
\end{tabular}


Table 4 Summary of relative risk ( $95 \%$ Cl excluding one) of adverse events occurring in $\geq 10 \%$ of patients in either of the treatment arms (Chinese safety population)

\begin{tabular}{|c|c|c|c|c|c|}
\hline \multirow[b]{2}{*}{ Preferred term } & \multirow[b]{2}{*}{ Pazopanib $(\boldsymbol{N}=109)$} & \multirow[b]{2}{*}{ Sunitinib $(\boldsymbol{N}=100)$} & \multicolumn{2}{|c|}{ Relative risk (pazopanib/sunitinib) } & \multirow[b]{2}{*}{$P$ value } \\
\hline & & & Ratio & $95 \% \mathrm{Cl}$ & \\
\hline Skin hypopigmentation & $13(12)$ & $3(3)$ & 3.98 & $(1.167-13.543)$ & 0.0270 \\
\hline Hair color changes & $47(43)$ & $13(13)$ & 3.32 & $(1.912-5.755)$ & $<0.001$ \\
\hline Diarrhea & $57(52)$ & $37(37)$ & 1.41 & $(1.034-1.932)$ & 0.0309 \\
\hline Blood creatinine increased & $21(19)$ & $32(32)$ & 0.60 & $(0.373-0.972)$ & 0.0362 \\
\hline Neutrophil count decreased & $25(23)$ & $40(40)$ & 0.57 & $(0.377-0.872)$ & 0.0086 \\
\hline Platelet count decreased & $23(21)$ & $39(39)$ & 0.54 & $(0.349-0.838)$ & 0.0059 \\
\hline Eyelid edema & $16(15)$ & $28(28)$ & 0.52 & $(0.302-0.910)$ & 0.0200 \\
\hline Thrombocytopenia & $20(18)$ & $39(39)$ & 0.47 & $(0.295-0.750)$ & 0.0016 \\
\hline White blood cell count decreased & $17(16)$ & $33(33)$ & 0.47 & $(0.281-0.794)$ & 0.0044 \\
\hline Blood lactate dehydrogenase increased & $9(8)$ & $18(18)$ & 0.46 & $(0.216-0.974)$ & 0.0429 \\
\hline Blood thyroid stimulating hormone increased & $8(7)$ & $19(19)$ & 0.39 & $(0.177-0.843)$ & 0.0179 \\
\hline Peripheral edema & $6(6)$ & $14(14)$ & 0.39 & $(0.157-0.984)$ & 0.0440 \\
\hline Hemoglobin decreased & $13(12)$ & $31(31)$ & 0.38 & $(0.214-0.693)$ & 0.0013 \\
\hline Stomatitis & $4(4)$ & $12(12)$ & 0.31 & $(0.102-0.917)$ & 0.0362 \\
\hline Anemia & $7(6)$ & $25(25)$ & 0.26 & $(0.116-0.568)$ & $<0.001$ \\
\hline Nasopharyngitis & $2(2)$ & $10(10)$ & 0.18 & $(0.041-0.817)$ & 0.0244 \\
\hline Facial edema & $3(3)$ & $17(17)$ & 0.16 & $(0.049-0.536)$ & 0.0052 \\
\hline Yellow skin & $3(3)$ & $22(22)$ & 0.13 & $(0.039-0.405)$ & $<0.001$ \\
\hline Xanthochromia & $1(<1)$ & $10(10)$ & 0.09 & $(0.012-0.704)$ & 0.0203 \\
\hline
\end{tabular}

Cl Confidence interval

first-line treatment regimens for favorable risk a/mRCC patients, and optimization is more important.

This study has certain limitations. The Chinese subgroup in the COMPARZ study was not randomized. Also, sunitinib treatment regimen in this study was the standard $4 / 2$ schedule (sunitinib $50 \mathrm{mg} /$ day; 4 weeks on treatment, 2 weeks off), while in routine clinical practice, dosing regimens for Chinese patients receiving sunitinib are often adjusted to mitigate toxicity. The small sample size of Chinese patients and limited efficacy analysis as per MSKCC / Heng risk category population are also limitations in this study.

\section{Conclusions}

The efficacy was similar with pazopanib and sunitinib arms in Chinese patients in terms of PFS and OS endpoints, consistent with the overall population in the COMPARZ study. Pazopanib was generally well tolerated in the Chinese population. There were no new safety signals for pazopanib in the Chinese subgroup.

\section{Abbreviations}

AE: Adverse event; BIRC: Blinded independent review committee; $\mathrm{Cl}$ : Confidence interval; HR: Hazard ratio; IRC: Independent review committee; ITT: Intent to treat; mTOR: mammalian target of rapamycin; ORR: Overall response rate; OS: Overall survival; PD: Progressive disease; PFS: Progressionfree survival; QD: Once daily; QOL: Quality of life; RCC: Renal cell carcinoma; TKI: Tyrosine kinase inhibitor; VEGFR: Vascular endothelial growth factor receptors

\section{Acknowledgements}

We thank all Chinese patients and investigators who participated in the COMPARZ study (NCT00720941 and NCT01147822). We thank Dr. Liping Xie for his contributions to the NCT01147822 study. Manuscript writing support was provided by Aarti Kamaraj (Novartis Healthcare Pvt. Ltd.). Results of this manuscript were partly included in the ASCO 2018 abstract accepted for online publication [Sheng X, Jin J, He Z, et al. Efficacy and safety of pazopanib (PAZ) versus sunitinib (SUN) in patients (pts) with locally advanced or metastatic renal cell carcinoma (RCC): A pooled China subgroup analysis from COMPARZ studies. J Clin Oncol 2018; 36(15_suppl): e16588.]

\section{Authors' contributions}

XS and JG contributed to the study design, supported statistical analysis, recruited patients, provided inputs for data interpretation and contributed to the writing and review of the content of the manuscript. JJ, ZH, YH, AZ, JW, $X R, D Y, X Z, S Q$ and FZ recruited patients and critically reviewed the content of the manuscript. BW supported statistical analysis and was involved in writing and critical review of the content of the manuscript. All authors read and approved the final draft of the manuscript for publication.

\section{Funding}

This study was sponsored by GlaxoSmithKline. The sponsor contributed to study design, collected and analyzed the data and the authors interpreted the data. Pazopanib is now an asset of Novartis Pharmaceuticals Corporation. Manuscript writing support was funded by Novartis and provided by Aarti Kamaraj (Novartis Healthcare Pvt. Ltd.)

\section{Availability of data and materials}

Novartis is committed to sharing with qualified external researchers, access to patient-level data and supporting clinical documents from eligible studies. These requests are reviewed and approved by an independent review panel on the basis of scientific merit. All data provided are anonymized to respect the privacy of patients who have participated in the trial in line with applicable laws and regulations. 
This trial data availability is according to the criteria and process described on www.clinicalstudydatarequest.com

\section{Ethics approval and consent to participate}

The study protocol with any amendments, informed consent, and other information that required preapproval were reviewed and approved by the investigational center ethics committee or institutional review board in China as required.

\begin{tabular}{|c|c|c|c|}
\hline Study center & Ethics committee & $\begin{array}{l}\text { NCT00720941 } \\
\text { Clinical trial } \\
\text { approval No. }\end{array}$ & $\begin{array}{l}\text { NCT01147822 } \\
\text { Clinical trial } \\
\text { approval No. }\end{array}$ \\
\hline $\begin{array}{l}\text { Beijing Cancer } \\
\text { Hospital, Beijing }\end{array}$ & $\begin{array}{l}\text { Ethics Committee of } \\
\text { Beijing Cancer Hospital }\end{array}$ & $\begin{array}{l}2009 L 09895 \\
2009 L 09896\end{array}$ & $\begin{array}{l}2010 L 00302 \\
2010 L 00301\end{array}$ \\
\hline $\begin{array}{l}\text { Peking University } \\
\text { First Hospital, Beijing }\end{array}$ & $\begin{array}{l}\text { National Ethics } \\
\text { Committee for clinical } \\
\text { trials of drugs of } \\
\text { Peking University First } \\
\text { Hospital }\end{array}$ & $\begin{array}{l}2009 L 09895 \\
2009 L 09896\end{array}$ & $\begin{array}{l}2010 \text { L00302 } \\
2010 \text { L00301 }\end{array}$ \\
\hline $\begin{array}{l}\text { Ren Ji hospital } \\
\text { affiliated to } \\
\text { Shanghai Jiao Tong } \\
\text { University, Shanghai }\end{array}$ & $\begin{array}{l}\text { Ethics Committee of } \\
\text { Ren Ji hospital } \\
\text { affiliated to Shanghai } \\
\text { Jiao Tong University }\end{array}$ & $\begin{array}{l}2009 \text { L09895 } \\
2009 \text { L09896 }\end{array}$ & $\begin{array}{l}2010 \text { L00302 } \\
2010 \text { L00301 }\end{array}$ \\
\hline $\begin{array}{l}\text { Cancer Hospital } \\
\text { Chinese Academy of } \\
\text { Medical Science, } \\
\text { Beijing }\end{array}$ & $\begin{array}{l}\text { Ethics Committee of } \\
\text { Chinese Academy of } \\
\text { Medical Science }\end{array}$ & $\begin{array}{l}2009 L 09895 \\
2009 L 09896\end{array}$ & $\begin{array}{l}2010 \text { L00302 } \\
2010 \text { L00301 }\end{array}$ \\
\hline $\begin{array}{l}\text { Tianjin Cancer } \\
\text { Hospital, Tianjin }\end{array}$ & $\begin{array}{l}\text { Medical Ethics } \\
\text { Committee of Tianjin } \\
\text { Cancer Hospital }\end{array}$ & $\begin{array}{l}2009 \text { L09895 } \\
2009 \text { L09896 }\end{array}$ & $\begin{array}{l}2010 \text { L00302 } \\
2010 \text { L00301 }\end{array}$ \\
\hline $\begin{array}{l}\text { Cancer Hospital } \\
\text { Affiliated to Fudan } \\
\text { University, Shanghai }\end{array}$ & $\begin{array}{l}\text { Medical Ethics } \\
\text { Committee of Cancer } \\
\text { Hospital Affiliated to } \\
\text { Fudan University }\end{array}$ & $\begin{array}{l}2009 L 09895 \\
2009 L 09896\end{array}$ & $\begin{array}{l}2010 \text { L00302 } \\
2010 \text { L00301 }\end{array}$ \\
\hline $\begin{array}{l}\text { Chinese PLA } \\
\text { General Hospital, } \\
\text { Beijing }\end{array}$ & $\begin{array}{l}\text { Medical Ethics } \\
\text { Committee of Chinese } \\
\text { PLA General Hospital }\end{array}$ & $\begin{array}{l}2009 \text { L09895 } \\
2009 L 09896\end{array}$ & $\begin{array}{l}2010 \text { L00302 } \\
2010 \text { L00301 }\end{array}$ \\
\hline $\begin{array}{l}\text { Chinese PLA Cancer } \\
\text { Center, Nanjing Bayi } \\
\text { Hospital, Nanjing }\end{array}$ & $\begin{array}{l}\text { Ethics Committee of } \\
\text { Nanjing Bayi Hospital }\end{array}$ & $\begin{array}{l}2009 \text { L09895 } \\
2009 \text { L09896 }\end{array}$ & $\begin{array}{l}2010 \text { L00302 } \\
2010 \text { L00301 }\end{array}$ \\
\hline $\begin{array}{l}\text { Sun Yat-Sen Univer- } \\
\text { sity Cancer Center, } \\
\text { Guangzhou }\end{array}$ & $\begin{array}{l}\text { Ethics Committee of } \\
\text { Sen University Cancer } \\
\text { Center }\end{array}$ & $\begin{array}{l}2009 \text { L09895 } \\
2009 \text { L09896 }\end{array}$ & $\begin{array}{l}2010 \text { L00302 } \\
2010 \text { L00301 }\end{array}$ \\
\hline $\begin{array}{l}\text { The First Affiliated } \\
\text { Hospital of Medical } \\
\text { School of Zhejiang } \\
\text { University } \\
\text { Hangzhou }\end{array}$ & $\begin{array}{l}\text { Ethics Committee of } \\
\text { The First Affiliated } \\
\text { Hospital of Medical } \\
\text { School of Zhejiang } \\
\text { University }\end{array}$ & / & $\begin{array}{l}2010 \text { L00302 } \\
2010 \text { L00301 }\end{array}$ \\
\hline
\end{tabular}

Written informed consent was obtained from each patient before performing any study-specific procedures.

\section{Consent for publication}

Not applicable.

\section{Competing interests}

BW is an employee of Beijing Novartis Pharma Co., Ltd. All other authors have no conflict of interest to declare.

\section{Author details}

${ }^{1}$ Key Laboratory of Carcinogenesis and Translational Research (Ministry of Education/Beijing), Department of Renal Cancer and Melanoma, Peking University Cancer Hospital \& Institute, Beijing, China. ${ }^{2}$ Peking University First Hospital, Beijing, China. ${ }^{3}$ Ren Ji hospital affiliated to Shanghai Jiao Tong
University, Shanghai, China. ${ }^{4}$ Cancer Hospital, CAMS \& PUMC, Beijing, China ${ }^{5}$ Tianjin Cancer Hospital, Tianjin, China. ${ }^{6}$ Cancer Hospital Affiliated to Fudan University, Shanghai, China. ${ }^{7}$ Chinese Beijing 301 PLA Hospital, Department of Urology, Beijing, China. ${ }^{8}$ PLA Cancer Center, Nanjing Bayi Hospital, Nanjing, China. ${ }^{9}$ Sun Yat-Sen University Cancer Center, Guangzhou, China. ${ }^{10}$ Novartis Oncology, Beijing, China.

Received: 8 March 2019 Accepted: 3 March 2020

Published online: 14 March 2020

\section{References}

1. Deveson KS. Renal cell carcinoma: treatment options. Br J Nurs. 2011;20(9): 536-9.

2. Guo J, Ma J, Sun Y, Qin S, Ye D, Zhou F, et al. Chinese guidelines on the management of renal cell carcinoma (2015 edition). Ann Transl Med. 2015; 3(19):279.

3. Wan XM, Peng LB, Ma JA, Li YJ. Economic evaluation of nivolumab as a second-line treatment for advanced renal cell carcinoma from US and Chinese perspectives. Cancer. 2017;123(14):2634-41.

4. Choueiri TK, Motzer RJ. Systemic therapy for metastatic renal-cell carcinoma. N Engl J Med. 2017;376(4):354-66.

5. Tan X, Liu Y, Hou J, Cao G. Targeted therapies for renal cell carcinoma in Chinese patients: focus on everolimus. Onco Targets Ther. 2015;8:313-21.

6. Zhang $\mathrm{H}-\mathrm{L}$, Qin $\mathrm{X}-\mathrm{J}$, Wang $\mathrm{H}-\mathrm{K}, \mathrm{Gu}$ W-J, Ma C-G, Shi G-H, et al. Clinicopathological and prognostic factors for long-term survival in Chinese patients with metastatic renal cell carcinoma treated with sorafenib: a single-center retrospective study. Oncotarget. 2015;6(34):36870-83.

7. Zhang H-L, Sheng X-N, Li X-S, Wang H-K, Chi Z-H, He Z-S, et al. Sorafenib versus sunitinib as first-line treatment agents in Chinese patients with metastatic renal cell carcinoma: the largest multicenter retrospective analysis of survival and prognostic factors. BMC Cancer. 2017;17(1):16.

8. Motzer RJ, Hutson TE, Cella D, Reeves J, Hawkins R, Guo J, et al. Pazopanib versus sunitinib in metastatic renal-cell carcinoma. N Engl J Med. 2013; 369(8):722-31

9. Gore ME, Szczylik C, Porta C, Bracarda S, Bjarnason GA, Oudard S, et al. Safety and efficacy of sunitinib for metastatic renal-cell carcinoma: an expanded-access trial. Lancet Oncol. 2009;10(8):757-63.

10. Kim HS, Hong MH, Kim K, Shin SJ, Ahn JB, Jeung HC, et al. Sunitinib for Asian patients with advanced renal cell carcinoma: a comparable efficacy with different toxicity profiles. Oncology. 2011;80(5-6):395-405.

11. He Z, Guo G, Zhang C, Li X, Fu W, Jin J, Zhang X, Zhou L. Efficacy of sunitinib in patients with metastatic renal cell carcinoma: initial experience in two Chinese centers. Chin Med J. 2014;127(8):1450-3.

12. Yoo C, Kim JE, Lee JL, Ahn JH, Lee DH, Lee JS, et al. The efficacy and safety of sunitinib in korean patients with advanced renal cell carcinoma: high incidence of toxicity leads to frequent dose reduction. Jpn J Clin Oncol. 2010;40(10):980-5

13. Zhou A. Management of sunitinib adverse events in renal cell carcinoma patients: the Asian experience. Asia Pac J Clin Oncol. 2012;8(2):132-44.

\section{Publisher's Note}

Springer Nature remains neutral with regard to jurisdictional claims in published maps and institutional affiliations.

Ready to submit your research? Choose BMC and benefit from:

- fast, convenient online submission

- thorough peer review by experienced researchers in your field

- rapid publication on acceptance

- support for research data, including large and complex data types

- gold Open Access which fosters wider collaboration and increased citations

- maximum visibility for your research: over $100 \mathrm{M}$ website views per year

At BMC, research is always in progress.

Learn more biomedcentral.com/submission 